\title{
Sosialisasi Aplikasi Program Visum dalam Estimasi Kebutuhan Perjalanan bagi Pemangku Kepentingan Perencanaan Transportasi di Kota Makassar
}

\author{
Hajriyanti Yatmar*, M.I Ramli, Mubassirang Pasra \\ Departemen Teknik Sipil, Fakultas Teknik Universitas Hasanuddin \\ hajriyanti.yatmar@gmai.com*
}

\begin{abstract}
Abstrak
Pola pergerakan dalam sistem transportasi sering dijelaskan dalam bentuk arus pergerakan (kendaraan, penumpang, dan barang) yang bergerak dari zona asal ke zona tujuan di dalam daerah tertentu dan selama periode waktu tertentu. Permintaan akan kebutuhan perjalanan ini sangat penting untuk keperluan perencanaan baik sarana dan prasarana khususnya transportasi. Angkutan umum menjadi salah satu moda transportasi untuk memenuhi kebutuhan perjalanan penumpang. Sebaran pergerakan perjalanan angkutan umum menjadi sangat penting untuk melihat distribusi pembebanan angkutan umum pada seluruh trayek yang ada. Distribusi pergerakan ini dapat dibuat dalam simulasi program Visumm yang memuat informasi bangkitan dan tarikan dari penumpang. Sosialisasi bagi pemangku kepentingan terkait dapat menjadi sangat bermanfaat dalam merancang dan merencanakan tatanan transportasi lokal. Kegiatan sosialisasi dengan pelatihan secara langsung ini diharapkan dapat memberikan gambaran secara visual dan menghasilkan proyeksi pola perjalanan penumpang dan kendaraan berdasarkan matriks asal dan tujuan dengan waktu yang lebih efisien. Sosialisasi aplikasi program visum ini juga diharapkan dapat memberikan pendekatan alternatif terkait model makroskopik dalam mengembangkan rencana jaringan jalan transportasi khususnya bagi pemangku kepentingan perencana transportasi di Kota Makassar.
\end{abstract}

Kata Kunci: Pejalanan; Angkutan umum; Jaringan jalan; Macroscopic model; Visum.

\begin{abstract}
The trip distribution in transportation system usually describes as a traffic flow (vehicles, passengers, and freight) moves from origin to destination of period time. The trip distribution plays important role for plan and decelopmet of transportation. The public transport is one of the transportation moda to fulfill the demand of travel along the existing route. The trip distribution is conducted in simulation program Visum that containing the information of production and attraction of passengers. The training of program is aims to produces the visual of trip distribution and estimation of trip forecast of vehicles and passengers based on origin and destination matrices with more efficient. The training of the application of Visum program also useful to perform an alternative approach due to mascroscopic model in developing the plan of road network to transportation stakeholder in Makassar. The simulation using the Visum not only for existing condition but also to predict the forecast of transportation planning especially the trip of vehicles and passengers.
\end{abstract}

Keywords: Trip; Public Transport; Road Network; Macroscopic model; Visum.

\section{Pendahuluan}

Pola pergerakan dalam sistem transportasi sering dijelaskan dalam bentuk arus pergerakan (kendaraan, penumpang, dan barang) yang bergerak dari zona asal ke zona tujuan di dalam daerah tertentu dan selama periode waktu tertentu. Permintaan akan kebutuhan perjalanan ini sangat penting untuk keperluan perencanaan baik sarana dan prasarana khususnya transportasi. Sebagai salah satu kota metropolitan, kebutuhan penyediaan sarana transportasi bagi masyarakat menjadi kebutuhan utama dalam melakukan pergerakan. Pesatnya pertambahan penduduk di 
suatu wilayah akan mempengaruhi aktivitas pergerakan dan perekonomian masyarakat, dengan demikian kebutuhan akan transportasi juga semakin meningkat. Ketersediaan angkutan umum idealnya memenuhi dua kepentingan yang berbeda yaitu pengguna jasa (demand) dan (supply).

Salah satu jenis angkutan umum yang beroperasi di Makassar adalah mikrolet. Mikrolet ini telah lama beroperasi dan menjadi moda transportasi lokal masyarakat Makassar. Data yang diperoleh dari Dinas Perhubungan Kota Makassar, mikrolet ini melayani 16 rute trayek dengan total jumlah armada 4.550. Dari keseluruhan jumlah trayek, saat ini hanya sebagian besar saja yang masih beroperasi sesuai dengan rutenya bergantung pada tingkat keterisian penumpang dan bahkan sering terjadi pemotongan rute untuk meminimalkan biaya operasional. Sehingga tak jarang mikrolet beroperasi pada zona atau wilayah tertentu yang potensial penumpang. Dengan mengetahui tingkat kebutuhan perjalanan penumpang berdasarkan pola pergerakannya maka kita dapat mengetahui rute operasional yang maksimal dan berbasis aplikasi.

Sebaran pergerakan perjalanan angkutan umum menjadi sangat penting untuk melihat distribusi pembebanan angkutan umum pada seluruh trayek yang ada. Dari informasi ini maka terlihat jelas rute maksimal yang sering dilalui oleh angkutan umum berdasarkan kebutuhan perjalanan penumpangnya. Hal ini menjadi acuan untuk mengevaluasi rute trayek kondisi eksisting sehingga dapat terbentuk jaringan jalan yang baru yang efektif dan efisien sesuai permintaan.

Angkutan umum atau mikrolet ini tidak memiliki lokasi pemberhentian tetap untuk menaik turunkan penumpang seperti halte. Mikrolet bebas berhenti di sepanjang titik yang ada pada trayek sehingga pada beberapa kondisi dapat menimbulkan antrian kendaraan karena menggunakan badan jalan untuk berhenti. Kondisi ini banyak kita jumpai dan terkadang menimbulkan permasalahan khususnya pada arus lalu lintas sedang padat di pagi dan sore hari. Bahkan, petugas keamanan dan beberapa dinas terkait turut serta untuk menertibkan sopir yang melakukan pemberhentian pada titik-titik yang rawan akan macet.

Identifikasi kebutuhan perjalanan oleh penumpang angkutan umum yang berada pada sepanjang zona trayek menjadi penting untuk diketahui agar dapat mengurangi antrian yang disebabkan oleh aktivitas mikrolet ini. Pembebanan kendaraan pada setiap zona yang ada disepanjang rute trayek dapat dibentuk dengan mengetahui asal dan tujuan dari setiap penumpang yang naik dan turun dalam mikrolet. Pembebanan kendaraan dan jumlah penumpang ini kemudian dapat dimodelkan dalam sebuah aplikasi atau software pemodelan transportasi yakni Visum.

Kendaraan umum yang beroperasi berdasarkan kebutuhan perjalanan penumpang kemudian dibuat dalam bentuk simulasi berdasarkan data pembebanan angkutan umum untuk setiap trayek dalam program Visum. Selanjutnya, untuk pola sebaran penumpang angkutan umum dalam rute trayek dibuat kedalam matriks asal tujuan yang dianalisa menggunakan Model Gravity. Titik-titik identifikasi pembebanan kendaraan dari pola pergerakan kendaraan dan penumpang ini dapat terlihat secara jelas pada Model Simulasi sehingga memberikan informasi akurat dalam mendukung pengaturan atau manajemen lalu lintas khususnya rute operasional angkutan umum. Pada akhirnya sosialisasi program ini diharapkan dapat bermanfaat dalam hal perencanaan dan pengembangan jaringan jalan untuk operasional rute di setiap trayek angkutan umum secara optimal, efektif dan efisien serta masukan bagi pemangku kebijakan transportasi untuk mengetahui kondisi pembebenan lalu lintas yang terjadi melalui aplikasi pemodelan. Untuk itu pada pelaksanaan program ini, mitra kerjasama adalah Dinas Perhubungan Kota Makassar. 
Metode pemodelan dan simulasi adalah elemen penting dalam analisis perencanaan dan operasional transportasi. Metode ini umumnya adalah formulasi secara matematis yang menunjukkan aktivitas pergerakan perjalanan untuk menghasilkan prediksi terhadap kemungkinan pola pergerakan, kinerja jaringan jalan, dan simpang pada masa yang akan datang. Perkembangan terkini pada teknologi software secara langsung meningkatkan kapasitas pemodelan transportasi. Saat ini metode simulasi telah dapat memberikan gambaran secara visual mewakili perilaku lalu lintas sebagai output sehingga memungkinkan pengguna sepenuhnya menghargai dampak skema yang diusulkan.

Dari hasil sosialisasi ini, seluruh peserta diharapkan mampu untuk membangun model jaringan transportasi dan jalan raya, memahami pendekatan alternatif dalam pemodelan makroskopik serta mendapatkan keterampilan dasar dalam pengelolaan software ini.

\section{Latar Belakang Teori}

Pemodelan bangkitan pergerakan bertujuan untuk mendapatkan jumlah pergerakan yang dibangkitkan oleh setiap zona asal (Oi) dan jumlah pergerakan yang tertarik ke setiap zona tujuan (Dd) yang ada di dalam daerah kajian (O. Tamin 2005). Besarnya pergerakan yang dihasilkan dari zona asal dan yang tertarik ke zona tujuan dibuat dalam matriks. Besarnya bangkitan dan tarikan pergerakan merupakan informasi yang sangat berharga yang dapat digunakan untuk memperkirakan besarnya pergerakan antarzona untuk perencanaan transportasi (Isran, 2007). Informasi terkait bangkitan dan tarikan penumpang yang ada dibuat dalam sebuah matriks asal tujuan (MAT). Pola pergerakan dapat dihasilkan jika suatu MAT dibebankan ke suatu sistem jaringan transportasi. Dengan mempelajari pola pergerakan yang terjadi, seseorang dapat mengidentifikasi permasalahan yang timbul sehingga beberapa solusi segera dapat dihasilkan. MAT dapat memberikan indikasi rinci mengenai kebutuhan akan pergerakan sehingga MAT memegang peran yang sangat penting dalam berbagai kajian perencanaan dan manajemen transportasi (Ofyar \& Willumsen, 2010).

MAT adalah matriks berdimensi dua yang setiap baris dan kolomnya menggambarkan zona asal dan tujuan di dalam daerah kajian (termasuk juga zona di luar daerah kajian), seperti terlihat pada tabel 5.1, sehingga setiap sel matriks berisi informasi pergerakan antarzona. Sel dari setiap baris i berisi informasi mengenai pergerakan yang berasal dari zona i tersebut ke setiap zona tujuan $\mathrm{d}$. Sel pada diagonal berisi informasi mengenai pergerakan intrazona $(i=d)$ (Willumsen \& Tamin 2008). Oleh karena itu:

Tid = pergerakan dari zona asal i ke zona tujuan $\mathrm{d}$

Oi $\quad=$ jumlah pergerakan yang berasal dari zona asal $\mathrm{i}$

Dd = jumlah pergerakan yang menuju ke zona tujuan $\mathrm{d}$

$\{$ Tid $\}$ atau $\mathrm{T}=$ total matriks 
Tabel 1. Bentuk Umum dari Matriks Asal - Tujuan

\begin{tabular}{|c|c|c|c|c|c|c|}
\hline Zone & 1 & 2 & 3 & $\ldots$ & $\mathrm{n}$ & $\mathrm{O}_{\mathrm{i}}$ \\
\hline \hline 1 & $\mathrm{~T}_{11}$ & $\mathrm{~T}_{12}$ & $\mathrm{~T}_{13}$ & $\ldots$ & $\mathrm{T}_{1 \mathrm{n}}$ & $\mathrm{O}_{1}$ \\
\hline 2 & $\mathrm{~T}_{21}$ & $\mathrm{~T}_{22}$ & $\mathrm{~T}_{22}$ & $\ldots$ & $\mathrm{T}_{2 \mathrm{n}}$ & $\mathrm{O}_{2}$ \\
\hline 3 & $\mathrm{~T}_{31}$ & $\mathrm{~T}_{32}$ & $\mathrm{~T}_{33}$ & $\ldots$ & $\mathrm{T}_{3 \mathrm{n}}$ & $\mathrm{O}_{3}$ \\
\hline$\ldots$ & $\ldots$ & $\ldots$ & $\ldots$ & $\ldots$ & $\ldots$ & $\ldots$ \\
\hline$\ldots$ & $\ldots$ & $\ldots$ & $\ldots$ & $\ldots$ & $\ldots$ & $\ldots$ \\
\hline $\mathrm{N}$ & $\mathrm{T}_{11}$ & $\mathrm{~T}_{11}$ & $\mathrm{~T}_{11}$ & $\ldots$ & $\mathrm{T}_{11}$ & $\mathrm{O}_{\mathrm{n}}$ \\
\hline $\mathrm{Dj}$ & $\mathrm{D}_{1}$ & $\mathrm{D}_{2}$ & $\mathrm{D}_{3}$ & $\ldots$ & $\mathrm{D}_{\mathrm{n}}$ & $\mathrm{T}$ \\
\hline
\end{tabular}

Data dari lapangan terkait jumlah penumpang yang naik dan turun yang diobservasi secara langsung kemudian dilakukan estimasi menggunakan rumus gravity. Model gravity ini merupakan model sintesis berdasarkan perjalanan penumpang dengan data dari hasil observasi Origin Destination (OD) (Isran, 2006). Model estimasi ini kemudian dilakukan kalibrasi terhadap perjalanan penumpang pada angkutan umum (M.M Abdel-Aal, 2014). Angkutan umum atau biasa disebut para transit ini sebagai moda transportasi yang dapat menjadi salah satu penyebab kemacetan sehingga informasi terkait bangkitan dan tarikan penumpang sangat penting untuk dilakukan optimasi (Isran, 2016). Metode sintetis (interaksi spasial) yang paling terkenal dan sering digunakan adalah model gravity (GR) karena sangat sederhana sehingga mudah dimengerti dan digunakan. Model ini menggunakan konsep gravity yang diperkenalkan oleh Newton pada tahun 1686 yang dikembangkan dari analogi hukum gravitasi. Metode ini berasumsi bahwa ciri bangkitan dan tarikan pergerakan berkaitan dengan beberapa parameter zona asal sehinnga dapat diimplementasikan pada program Visum (Muralia, 2018), misalnya populasi dan nilai sel MAT yang berkaitan juga dengan aksesibilitas (kemudahan) sebagai fungsi jarak, waktu, atau pun biaya. Model ini mempunyai beberapa hal yang perlu diperhatikan. Dikatakan bahwa pergerakan antara zona asal i dan zona tujuan d berbanding lurus dengan Oi dan Dd dan berbanding terbalik kuadratis terhadap jarak antara kedua zona tersebut. Jadi, dalam bentuk matematis, model GR dapat dinyatakan sebagai:

$$
\text { Tid } \approx \text { Oi .Dd .Ai. Bd. f(Cid) }
$$

Ai dan Bd adalah konstanta yang terkait dengan setiap zona bangkitan dan tarikan. Untuk f (Cid) adalah fungsi hambatan yang dianggap sebagai ukuran aksesabilitas (kemudahan) Antara zona $i$ dan zona $d$ (Tamin O.Z., 2007). Hasil dari estimasi ini dapat dibuat dalam program Visum sehingga terlihat zona bangkitan dan tarikan serta validasi dari estimasi matriks asal dan tujuan dapat tercapai.

\section{Metode}

Kegiatan sosialisasi ini menjadi satu inovasi dalam hal pengembangan dan perencanaan transportasi khususnya Kota Makassar. Program sosialisasi ini kemudian dibuat dalam bentuk training atau workshop sehari dimana yang menjadi tutor adalah pihak perusahaan PTV Visum sendiri yang memiliki lisensi dari program tersebut dengan bantuan instruktur dari staff dan asisten laboratorium rekayasa transportasi. Sosialisasi ini dilakukan dengan training langsung dan 
studi kasus secara nyata dari data observasi lapangan yang telah dilakukan. Sehingga contoh kasus yang ada dan diimplementasikan pada program ini adalah contoh kasus nyata langsung sehingga memudahkan peserta untuk memahami aplikasi penggunaan program Visum ini.

Peserta yang mengikuti sosialisasi juga diharapkan dapat melakukan pemodelan dan simulasi terhadap potensial masalah transportasi yang ada khususnya model jaringan jalan dalam memenuhi kebutuhan pergerakan perjalanan oleh kendaraan/ angkutan umum (kendaraan, barang, jasa dan lainnya). Untuk itu partisipasi dari peserta/individu yang mengikuti sosialisasi ini diharapkan mampu memberikan masukan terkait permasalahan transportasi khususnya kebutuhan perjalanan dalam pemodelan, kendala, serta saran untuk pengembangan kegiatan.

Berdasarkan uraian di atas, maka untuk sosialisasi aplikasi software Visum bertujuan untuk:

a. Memberikan pengetahuan dan pembekalan bagi individu yang berminat mendalami pemodelan transportasi dan simulasi lalu lintas melalui praktek aplikasi software;

b. Mengetahui tahapan membangun jaringan model transportasi dan jalan raya; dan

c. Memberikan keterampilan dasar dalam pengolahan software untuk pemodelan makroskopik yang meliputi, pengantar pemodelan transportasi dengan PTV Visum, pengembangan model permintaan perjalanan 4 langkah, menyusun jaringan jalan dari data Google Earth dan Open Streeet Map, serta mengukur kinerja jaringan jalan dan mengetahui hasil keluaran.

Pelaksanaan program sosialisasi ini juga mengharapkan peserta mampu menggunakan aplikasi berdasarkan studi kasus yang akan diberikan pada saat sosialisasi. Untuk tahap keberlanjutan dari kegiatan ini, komunikasi dengan laboratorium sistem transportasi dapat menjadi wadah untuk konsultasi dan pendalaman terkait pemodelan transportasi menggunakan aplikasi PTV Visum dapat kembali dilakukan.

Kegiatan sosialisasi aplikasi Visum ini akan dilaksanakan di Departemen Teknik Sipil Unhas dengan registerasi peserta yang terbatas dan diutamakan untuk pihak-pihak yang terkait dan membutuhkan. Untuk itu sebelum kegiatan berlangsung, akan dilakukan registerasi secara online. Mengundang instruktur ahli yang telah berlisensi resmi oleh PTV Visum memberikan arahan dan bimbingan terkait penggunaan aplikasi ini bekerjasama dengan dosen ahli pada Laboratorium Sistem Tranportasi Departemen Teknik Sipil Unhas yang juga telah menggunakan dan mendapatkan lisensi dari aplikasi Visum.

Dinas Perhubungan Kota Makassar sebagai mitra mendukung dan memfasilitasi kegiatan berupa data-data jaringan jalan kota, arah pengembangan jaringan jalan, dan data pendukung lainnya untuk menghasilkan model yang akurat sesuai dengan kondisi lapangan.

Kegiatan sosialisasi ini diselenggarakan di kampus dan masing-masing peserta diharapkan membawa komputer yang kompatibel serta melakukan penginstalan software secara daring juga aplikasi lain yang akan mendukung jalannya program Visum. Peserta dari sosialisasi ini akan mendapatkan sertifikat telah mengikuti kegiatan dan mendapatkan pemahaman dasar tentang penggunaan dan pemanfaatan aplikasi Visum. 

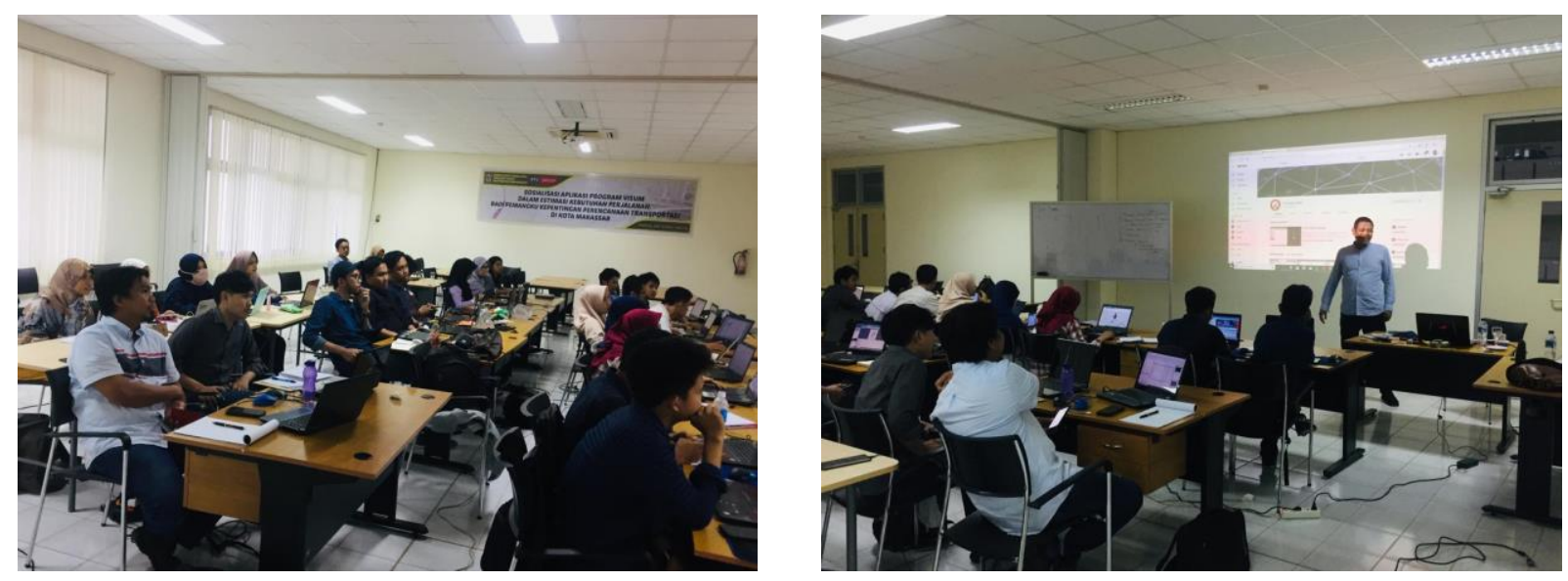

Gambar 1. Kegiatan Sosialisasi Aplikasi Program Visum

Kegiatan penelitian ini dikakukan dengan metode pelaksanaan yang terbagi atas 4 kelompok kegiatan utama yaitu:

a. Sosialisasi ke Stakeholder;

b. Sosialisasi ke Dinas terkait (Dinas Perhubungan, Dinas Perencanaan Wilayah Kota, dll);

c. Persiapan Modul; dan

d. Sosialisasi Aplikasi VISUM.

\section{Target Capaian}

Sosialisasi Aplikasi Visum diharapkan memberikan manfaat pada perencanaan dan pengembangan jaringan jalan dengan studi kasus yang real sehingga mudah terimplementasikan. Antusias dan dukungan dari peserta yang hadir akan menjadi bahan evaluasi dan pertimbangan terkait keberlanjutan sosialisasi pemanfaatan program untuk tingkat advance. Aplikasi Visum pada sosialisasi ini dilaksanakan untuk mengukur kebutuhan perjalanan angkutan umum Kota Makassar dan pembebanan angkutan umum pada setiap trayek yang ada. Hasil dari kegiatan sosialisasi ini diharapkan dapat memberikan informasi terkini sebagai preferensi bagi Dinas terkait dan akan dipublikasikan pada Jurnal TEPAT Fakultas Teknik Unhas. Dengan adanya penelitian ini, diharapkan dapat memberikan manfaat bagi pemegang kebijakan dalam manajemen lalu lintas dan mengurangi masalah transportasi. Penelitian ini juga diharapkan dapat menjadi prefensi bagi moda angkutan online (taksi online) terkait willingness penumpang yang masih menggunakan mau menggunakan angkutan umum atau taksi online yang bermanfaat untuk studi selanjutnya.

\section{Hasil dan Diskusi}

Proses pelaksanaan kegiatan pengabdian ini melibatkan peserta dari Dinas Perhubungan Kota Makassar dan mahasiswa riset laboratorium sistem transportasi dengan jumlah peserta sekitar 28 orang yang mengikuti proses pelaksanaan kegiatan dengan penyerapan materi optimal melalui pengecekan hasil model yang telah dibuat sesuai dengan contoh kasus lapangan yang ada. Hasil 
dan model yang telah dibangun juga memberikan inisiatif terhadap peserta untuk mencoba dengan berbagai jenis kasus lainnya. Model perjalanan yang telah dibuat dapat langsung terlihat dan mendukung dalam perencanaan jaringan jalan. Sosialisasi dan pelatihan yang berkelanjutan dibutuhkan untuk dapat memahami cakupan yang luas dalam pemanfaatan aplikasi program tersebut. Sehingga, kedepannya diharapkan ada wadah konsultasi untuk bisa mewadahi berbagai pertanyaan yang tidak sempat didiskusikan pada acara sosialisasi program tersebut khususnya bagi para pengguna atau stakeholder terkait.

\section{Kesimpulan}

Tingkat antusias peserta dalam mengikuti sosialisasi ini sangat baik mengingat program ini dapat membuat dan menunjang kinerja mereka dalam merencanakan dan mengembangkan jaringan jalan khususnya Kota Makassar. Program ini menjadi salah satu solusi bagi para pemangku kepentingan untuk dapat lebih mendorong pengembangan dan kemajuan jaringan transportasi yang ada sehingga tatanan transportasi dapat maju.

\section{Ucapan Terima Kasih}

Ucapan terima kasih kepada Fakultas Teknik, Departemen Teknik Sipil dan Dinas Perhubungan Kota Makassar yang telah memfasilitasi pelaksanaan kegiatan ini serta turut serta memberikan kontribusi dengan mendorong keaktifan para staff dan mahasiswa yang memiliki peminatan dalam mengembangkan ilmunya khususnya perencanaan transportasi kota.

\section{Daftar Pustaka}

Tamin, Ofyar Z. (2005). Integrated Public and Road Transport Network System for Bandung Metropolitan Area (Indonesia). Proceeding of the Eastern Asia Society for Transportation Studies, Vol. 5 pp 1281-1300.

Ali N., Ramli I. (2007). Optimization of Public Transport (Mini Bus) in Makassar with Break Event Point. Simposium X FSTPT, Tarumanegara University. Jakarta.

Willumsen, O.Z. Tamin. (2010). Transport Demand Model Estimation from Traffic Counts. Transportation 16: 3-26, 1989. Kluwer Academic Publishers. Netherlands.

Tamin O.Z., Willumsen L.G. (2008). Transport demand model estimation from traffic counts. Transportation 16: 3 - 26. Kluwer Academic Publishers. Netherland.

Nur Ali, Muhammad Isran Ramli, (2006). Studi Model Hubungan Volume-Kecepatan-Kepadatan Jalan Perkotaan Tipe 2 Lajur dan 4 Lajur Tak Terbagi. Jurnal Transportasi 2006.

Abdel-Al M.M.M. (2014). Calibrating a trip distribution gravity model stratified by the trip purposes for the city of Alexandria. Alexandria Engineering Journal (2014) 53, 677-689.

N K Nur., Lawalenna Samang., M. Isran ramli. (2016). Studi Preferensi Transformasi Moda Angkutan Umum berdasarkan Karaktersitik Perjalanan dan Perilaku Pengguna. Publikasi Ilmiah S3 Teknik Sipil Unhas, April 2016.

Muralia Hustim, Rasdiana Zakaria, Muhammad Isran Ramli, Zulfiani. (2018). The effect of speed factors and horn sound to the RLS 90 model reliability on the Visum program in predicting noise of heterogeneous traffic. International Journal of Integrated Engineering (Volume 10, Special Issue No. 2: Civil \& Environmental Engineering, 2018, Pages 77 to 81). 